\title{
Review Article \\ Cervical Carcinogenesis and Immune Response Gene Polymorphisms: A Review
}

\author{
Akash M. Mehta, ${ }^{1}$ Merel Mooij, ${ }^{2}$ Ivan Branković, ${ }^{2,3}$ Sander Ouburg, \\ Servaas A. Morré, ${ }^{2,3}$ and Ekaterina S. Jordanova ${ }^{1,4}$ \\ ${ }^{1}$ Department of Pathology, Leiden University Medical Centre, Leiden, Netherlands \\ ${ }^{2}$ Laboratory of Immunogenetics, Department of Medical Microbiology and Infection Control, VU University Medical Centre, \\ Amsterdam, Netherlands \\ ${ }^{3}$ Institute for Public Health Genomics, Department of Genetics and Cell Biology, School for Oncology and \\ Developmental Biology (GROW), Faculty of Health, Medicine and Life Sciences, Maastricht University, Maastricht, Netherlands \\ ${ }^{4}$ Centre for Gynaecological Oncology Amsterdam, Amsterdam, Netherlands
}

Correspondence should be addressed to Ekaterina S. Jordanova; e.jordanova@lumc.nl

Received 30 July 2016; Revised 28 November 2016; Accepted 18 December 2016; Published 9 February 2017

Academic Editor: Margarete D. Bagatini

Copyright (C) 2017 Akash M. Mehta et al. This is an open access article distributed under the Creative Commons Attribution License, which permits unrestricted use, distribution, and reproduction in any medium, provided the original work is properly cited.

The local immune response is considered a key determinant in cervical carcinogenesis after persistent infection with oncogenic, high-risk human papillomavirus (HPV) infections. Genetic variation in various immune response genes has been shown to influence risk of developing cervical cancer, as well as progression and survival among cervical cancer patients. We reviewed the literature on associations of immunogenetic single nucleotide polymorphism, allele, genotype, and haplotype distributions with risk and progression of cervical cancer. Studies on HLA and KIR gene polymorphisms were excluded due to the abundance on literature on that subject. We show that multiple genes and loci are associated with variation in risk of cervical cancer. Rather than one single gene being responsible for cervical carcinogenesis, we postulate that variations in the different immune response genes lead to subtle differences in the effectiveness of the antiviral and antitumour immune responses, ultimately leading to differences in risk of developing cervical cancer and progressive disease after HPV infection.

\section{Introduction}

Infection with human papillomavirus (HPV) is highly common across human populations. Worldwide, prevalence estimates of HPV infection among women range from $2 \%$ to $44 \%$ [1]. Invasive cervical carcinoma, which is caused by malignant transformation of cervical epithelial cells following persistent HPV infection, is one of the most common malignant diseases among women, representing almost $10 \%$ of all cancers in the female population. Each year, more than 500.000 women are diagnosed with cervical cancer, mostly in developing countries [2].

Approximately $200 \mathrm{HPV}$ types have been identified to date, with new types constantly being discovered. Types may differ in tissue tropism and may preferentially infect skin or mucosa. Certain HPV types are pathogenic, leading to a variety of benign conditions (genital, oral, and throat warts) as well as malignant disease (the most common being cervical, penile, vulvar, vaginal, and oesophageal carcinoma) $[3,4]$. HPV types 16 and 18 are responsible for approximately $60-80 \%$ of all cervical cancer cases, while types 52 and 31 account for the majority of the remaining cases. However, HPV distribution patterns differ significantly amongst various populations [5].

Although infection and colonisation of the cervical epithelium by oncogenic, high-risk human papilloma viruses (hr-HPVs) are prerequisites for the development of cervical cancer, the local immune response is thought to be an important determinant of progression and disease outcome [6]. The higher incidence of HPV-associated cervical dysplasia in immunosuppressed patients supports the hypothesis that local immune responses are an important determinant 
in transformation of epithelial cells [6]. The transiency of most HPV infections and the observed regression of certain cervical intraepithelial neoplasia (CIN) lesions to normal epithelium suggest a variability in local immune responses, which may be caused by differences in host genomics [7].

Genetic variation in various immune mediators has been shown to be an important determinant in susceptibility to a wide variety of autoimmune disorders and neoplasms, as well as in progression and disease outcome [8-10]. This is especially the case for HPV-related epithelial transformation [11]. Understanding immunogenetic variation is necessary not only to comprehend the striking heterogeneity in antiHPV and antitumour immune responses but also to enable and facilitate rational design of host-directed therapy and other novel treatment modalities. This review aims to provide an overview of common single nucleotide polymorphisms (SNPs) in genes encoding cytokines, chemokines, receptors, and antigen-processing machinery (APM) components and association with cervical carcinoma risk, progression, and/or outcome.

\section{Methods}

A systematic search in the NCBI PubMed bibliographic database and $\mathrm{HuGE}$ navigator was conducted [46]. Since major histocompatibility complex (MHC/HLA) and killer cell immunoglobulin-like receptor (KIR) genes have been abundantly studied in cervical cancer [47-55], these terms were excluded from the search. All original research studies and meta-analyses, published until August 1st 2015 and reporting on genes encoding any immune response mediators and either risk of cervical cancer or survival outcome amongst cervical cancer patients, were included.

Information on allele or genotype frequencies and, if available, odds or hazard ratios with associated 95\% confidence intervals were extracted from the studies. If unavailable in the original studies, these ratios were calculated along with the population attributable faction (PAF), according to Miettinen's formula [56].

\section{Cytokines}

Cytokines play a crucial role in mounting and maintaining immune responses against a host of pathogens, including viral infections and tumours [11]. Though many different classification systems exist for these signalling molecules, the most basic subdivision is that of proinflammatory and anti-inflammatory cytokines. A separate group is formed by chemokines, chemoattractant cytokines specifically involved in chemotaxis, the process by which different immune cells are recruited and signaled to migrate to certain sites to build a local inflammatory response. Among the most ubiquitous cytokines are the interleukins, which influence development and differentiation of lymphocytes and hematopoietic cells. Cytokines are produced by many different cells involved in the immune response; substantial evidence suggests that certain tumour cells, both in vitro and in vivo, also generate various cytokines $[57,58]$. Genetic variation in genes encoding proinflammatory (Table 1) and anti-inflammatory cytokines (Table 2) and chemokines (Table 3) may lead to altered function or quantity of the associated cytokines and is therefore believed to be an important determinant of antiHPV and antitumour immunity.

3.1. Proinflammatory Cytokines. Although several polymorphisms in the genes encoding various interleukins have been described in relation to cervical carcinoma and its precursor lesions [59-63], the most consistently reported SNP is in the promotor region of the $I L 1 B$ gene (c. $-511 \mathrm{C}>\mathrm{T}$ ) encoding interleukin-1 beta (mediator of the inflammatory response, cell proliferation, differentiation, and apoptosis), which has been demonstrated to be associated with cervical carcinoma risk in Korean, North Indian, Chinese Han, and Egyptian populations [12-15]. Two recent meta-analyses demonstrated significant association of the minor allele with increased cervical cancer risk $[16,64]$.

Several polymorphisms in the TNF gene, encoding tumour necrosis factor (TNF), have been described in relation to HPV infection and cervical neoplasia. TNF is a key proapoptotic cytokine, involved in cell proliferation and differentiation [65]. Variation at one site in the promotor region (c.-308G>A) has been found to be associated with development of CIN lesions and with susceptibility to HPV16 infection and subsequent cervical carcinoma in various populations. It has been hypothesised that the minor allele is associated with increased TNF production, which may be associated with induction of angiogenesis, a prerequisite for cancer cell growth and progression [17]. However, the genotypes associated with HPV-related epithelial transformation differed among the investigated populations: in a British cohort, all categories of CIN were associated with major allele homozygosity, while in Indo-Aryan and Portuguese women, the minor allele was associated with a threefold increase in susceptibility to cervical cancer and a twofold increased risk of developing cervical cancer in Portuguese women $[17,18,66]$. A recent meta-analysis demonstrated association of the minor allele with cervical cancer risk (OR 1.19; 95\% CI 1.02-1.38), although there was significant populationbased heterogeneity [67]. Data regarding other TNF gene polymorphisms, including microsatellite polymorphisms, is available but conflicting, probably due to small sample sizes [68-70].

Interferon-gamma $(\mathrm{IFN} \gamma)$ plays an important role in antiviral immunity [71]. Genetic variation of the c.874T $>$ A locus, located at the translation start site of the first intron of the IFNG gene, has been shown to be associated with altered levels of IFN $\gamma$ production in response to immunogenic stimuli, with minor allele carriers having decreased IFN $\gamma$ production [72]. In several North Indian cohorts, genotypes with the minor allele were associated with increased risk and with higher disease stage $[19,20]$. Minor allele homozygosity was also associated with increased cervical cancer risk in a Chinese population [21]. However, studies among Brazilian and Swedish populations did not find any significant associations of this polymorphism with cervical carcinoma [7375]. Two recent meta-analyses have demonstrated a clear association of the minor allele at this locus with increased cervical carcinoma risk; this association is the strongest 
TABLE 1: Overview of polymorphisms in genes encoding proinflammatory cytokines and association with cervical neoplasia risk.

\begin{tabular}{|c|c|c|c|c|c|c|c|}
\hline Gene & Polymorphism $^{\mathrm{a}}$ & Cohort & Cases $(n)$ & Population & Distribution & Risk (OR, 95\% CI); PAF ${ }^{\mathrm{b}, \mathrm{c}, \mathrm{d}}$ & Reference \\
\hline \multirow{6}{*}{$I L 1 B$} & \multirow{6}{*}{$\begin{array}{l}\text { c. }-511 C>T \\
(\mathrm{rs} 16944)\end{array}$} & \multirow{6}{*}{ Cervical cancer } & 182 & Korean & Genotypes & $\begin{array}{c}\text { CT: } 2.83(\mathbf{1 . 5 2 - 5 . 2 8 ) ; 4 4 . 8} \% \\
\text { TT: } 1.68(0.85-3.32) \\
\text { CT/TT: } 2.42(1.31-4.46) ; \\
\mathbf{5 4 . 2} \%\end{array}$ & {$[12]$} \\
\hline & & & 150 & $\begin{array}{l}\text { North } \\
\text { Indian }\end{array}$ & $\begin{array}{c}\text { Alleles } \\
\text { Genotypes }\end{array}$ & $\begin{array}{c}\text { T: } \mathbf{1 . 8 3}(\mathbf{1 . 2 8}-\mathbf{2 . 6 1}) ; \mathbf{3 3 . 9} \% \\
\text { CT: } 1.37(0.59-3.20) \\
\text { TT: } 2.77(\mathbf{1 . 2 1}-\mathbf{6 . 4 1}) ; \mathbf{3 6 . 6} \%\end{array}$ & {$[13]$} \\
\hline & & & 404 & $\begin{array}{l}\text { Chinese } \\
\text { Han }\end{array}$ & Genotypes & $\begin{array}{c}\text { CT: } 1.53(1.09-2.15) ; 19.5 \% \\
\text { TT: } 1.47(0.97-2.24) \\
\text { CT/TT: } 1.52(1.10-2.09) ; \\
\mathbf{2 6 . 2} \%\end{array}$ & {$[14]$} \\
\hline & & & & & Alleles & T: 2.00 (1.19-3.38); 37.5\% & \\
\hline & & & 100 & Egyptian & Genotypes & $\begin{aligned} \text { CT: } 0.72(0.36-1.43) \\
\text { TT: } 2.16(1.07-4.33) ; 30.6 \% \\
\text { CT/TT: } 2.91(\mathbf{1 . 0 1 - 8 . 3 6 ) ;} \\
\mathbf{6 1 . 0} \%\end{aligned}$ & {$[15]$} \\
\hline & & & 736 & Asian & Genotypes & $\begin{array}{c}\text { CT: } 1.69(1.29-2.22) \\
\text { TT: } 1.64(1.19-2.25) \\
\text { CT/TT: } 1.69(1.30-2.18)\end{array}$ & {$[16]$} \\
\hline \multirow[t]{3}{*}{ TNFA } & \multirow{3}{*}{$\begin{array}{l}\text { c. }-308 \mathrm{G}>\mathrm{A} \\
(\mathrm{rs} 1800629)\end{array}$} & Cervical cancer & 195 & $\begin{array}{c}\text { North } \\
\text { Portuguese }\end{array}$ & Genotypes & $\begin{array}{c}\text { GA: } 1.81(\mathbf{1 . 1 0}-\mathbf{2 . 9 7}) ; \mathbf{1 1 . 5} \% \\
\text { AA: } 2.54(0.65-10.52) \\
\text { GA/AA: } 1.88(1.20-2.94) \\
13.7 \%\end{array}$ & [17] \\
\hline & & Cervical cancer & 2279 & Varied & Alleles & A: $1.57(1.21-2.04)$ & {$[16]$} \\
\hline & & $\begin{array}{c}\text { Cervical cancer + } \\
\text { CIN }\end{array}$ & 165 & $\begin{array}{l}\text { Indo- } \\
\text { Aryan }\end{array}$ & Alleles & A: $2.70(1.41-5.15) ; 13.2 \%$ & {$[18]$} \\
\hline \multirow{6}{*}{$I F N G$} & \multirow{6}{*}{$\begin{array}{l}\text { c. }+874 \mathrm{~T}>\mathrm{A} \\
(\mathrm{rs} 2430561)\end{array}$} & \multirow{6}{*}{ Cervical cancer } & 200 & $\begin{array}{l}\text { North } \\
\text { Indian }\end{array}$ & Genotypes & $\begin{array}{c}\text { TA: } 3.30(2.05-5.20) ; 43.6 \% \\
\text { AA: } 1.90(0.90-3.90) \\
\text { TA/AA: } 2.90(1.90-4.60) \\
\mathbf{4 8 . 8} \%\end{array}$ & [19] \\
\hline & & & 200 & $\begin{array}{l}\text { North } \\
\text { Indian }\end{array}$ & $\begin{array}{c}\text { Alleles } \\
\text { Genotypes }\end{array}$ & $\begin{array}{c}\text { A: } 1.54(1.17-2.03) ; 23.0 \% \\
\text { TA: } 1.56(0.88-2.78) \\
\text { AA: } 2.43(1.34-4.42) ; 25.3 \%\end{array}$ & {$[20]$} \\
\hline & & & & & Alleles & A: 1.47 (1.10-1.97); 17.6\% & \\
\hline & & & 186 & Chinese & Genotypes & $\begin{array}{c}\text { TA: } 1.58(0.86-2.91) \\
\text { AA: } \mathbf{2 . 2 2}(\mathbf{1 . 1 9 - 4 . 1 5 )} ; \mathbf{2 4 . 0} \%\end{array}$ & [21] \\
\hline & & & 1116 & Varied & Genotypes & TA/AA: 1.399 (1.097-1.784) & {$[22]$} \\
\hline & & & 1532 & Varied & Alleles & $\mathrm{A}: 1.30(1.01-1.69)$ & {$[16]$} \\
\hline
\end{tabular}

$n$ : number of cases; OR: odds ratio; 95\% CI: 95\% confidence interval; CIN: cervical intraepithelial neoplasia; PAF: population attributable fraction.

${ }^{a}$ Nucleotide variation and dbSNP reference number.

${ }^{\mathrm{b}} \mathrm{OR}$ relative to major allele or major allele homozygotes.

${ }^{\mathrm{c}} \mathrm{PAF}$ listed if OR $>1.00$.

${ }^{\mathrm{d}}$ Significant associations listed in bold.

among Asian populations [16, 22]. Possible explanations for this difference among populations could include differences in HPV type distributions as well as in background host genomics.

3.2. Anti-Inflammatory Cytokines. The ILIRN gene encodes the interleukin-1 receptor antagonist (IL-1RA), which regulates the biological activity of the two potent proinflammatory cytokines interleukin- $1 \alpha$ and interleukin- $1 \beta$ [76]. Most of the genetic variation in this gene is attributed to a polymorphic 86-bp variable numbers tandem repeat (VNTR) in intron 2; five different allelic variants of this
VNTR have been described. Two studies among Indian populations showed association of genetic variation at this site with cervical carcinoma risk, with allele 2 bearing the strongest association with increased cancer risk [13, 77], both in single genotype analysis and in haplotype analysis with the ILIB gene. In contrast, a study of Austrian patients with high-grade CIN lesions demonstrated no significant association with the ILIRN VNTR polymorphic site [78]. Unfortunately, no data on HPV type distribution was reported in the Austrian study, rendering assumptions as to the cause of this difference between populations difficult. 
TABLE 2: Overview of polymorphisms in genes encoding anti-inflammatory cytokines and association with cervical neoplasia risk.

\begin{tabular}{|c|c|c|c|c|c|c|c|}
\hline Gene & Polymorphism $^{\mathrm{a}}$ & Cohort & Cases $(n)$ & Population & Distribution & Risk (OR, 95\% CI); PAF ${ }^{\mathrm{b}, \mathrm{c}, \mathrm{d}}$ & Reference \\
\hline \multirow[b]{2}{*}{$I L 1 R N$} & \multirow[b]{2}{*}{ VNTR alleles 1-5 } & \multirow[b]{2}{*}{ Cervical cancer } & \multirow[b]{2}{*}{150} & \multirow[b]{2}{*}{$\begin{array}{l}\text { North } \\
\text { Indian }\end{array}$} & Alleles & $\begin{array}{c}\text { 2: } 2.33(1.57-3.44) ; 19.4 \% \\
3: 0.89(0.27-2.77) \\
4: 1.00(0.18-5.33)\end{array}$ & \\
\hline & & & & & $\begin{array}{l}\text { Haplotypes } \\
\quad(I L R N- \\
V N T R / I L 1 B \\
\text { c. }-511 C>T)\end{array}$ & $\begin{array}{c}\text { 1/T: } 1.71(\mathbf{1} .12-2.62) ; 18.7 \% \\
\text { 2/C: } 1.98(0.95-4.14) \\
\text { 2/T: 4.08 (2.38-7.04); 20.1\% } \\
\text { 3/T: } 1.26(0.37-4.14) \\
\text { 4/T: } 1.89(0.29-2.23)\end{array}$ & {$[13]$} \\
\hline \multirow{4}{*}{ IL10 } & \multirow{4}{*}{$\begin{array}{l}\text { c. }-1082 A>G \\
(\mathrm{rs} 1800896)\end{array}$} & $\begin{array}{c}\text { CIN } \\
\text { Cervical cancer }\end{array}$ & $\begin{array}{l}163 \\
104\end{array}$ & Japanese & Genotypes & $\begin{array}{c}\text { CIN } \\
\text { AG/GG: } 2.2(1.2-4.2) ; 53.9 \% \\
\text { Cervical cancer } \\
\text { AG/GG: } 3.9(2.1-7.3) ; 70.8 \%\end{array}$ & {$[23]$} \\
\hline & & Cervical cancer & 77 & African & Genotypes & AG: $0.28(0.12-0.61)$ & {$[24]$} \\
\hline & & Cervical cancer & 667 & Caucasian & Alleles & G: $0.39(0.32-0.47)$ & {$[25]$} \\
\hline & & Cervical cancer & 256 & Indian & Genotypes & $\begin{array}{c}\text { AG/GG: } 3.67(2.33-5.77) \text {; } \\
52.2 \%\end{array}$ & {$[26]$} \\
\hline \multirow[b]{4}{*}{ IL10 } & \multirow[b]{4}{*}{$\begin{array}{l}\text { c. }-592 \mathrm{C}>\mathrm{A} \\
(\mathrm{rs} 1800872)\end{array}$} & Cervical cancer & 2396 & $\begin{array}{c}\text { Asian } \\
\text { Caucasian }\end{array}$ & Alleles & A: $1.16(1.04-1.31)$ & {$[25]$} \\
\hline & & \multirow{2}{*}{$\begin{array}{l}\text { Cervical cancer } \\
\text { Squamous } \\
\text { intraepithelial } \\
\text { cervical lesions }\end{array}$} & 2183 & Varied & Alleles & A: $1.17(1.04-1.33)$ & {$[16]$} \\
\hline & & & 204 & Mexican & Genotypes & $\begin{aligned} \text { A: } 1.32(0.97-1.81) \\
\text { CA/AA: } \mathbf{2 . 0 2 ( 1 . 2 6 - 3 . 2 5 )} \\
\mathbf{3 8 . 4} \%\end{aligned}$ & {$[27]$} \\
\hline & & $\begin{array}{c}\text { CIN II/III } \\
\text { Cervical cancer }\end{array}$ & $\begin{array}{l}263 \\
667\end{array}$ & Dutch & Genotypes & $\begin{array}{c}\text { CIN } \\
\text { CA: 1.44 (1.06-1.97); 11.2\% } \\
\text { AA: } 1.09(0.53-2.26) \\
\text { CA/AA: } \mathbf{1 . 4 0}(\mathbf{1 . 0 4}-\mathbf{1 . 8 8}) \text {; } \\
\mathbf{1 1 . 7} \% \\
\text { Cervical cancer } \\
\text { CA: } 1.36(\mathbf{1 . 0 7}-\mathbf{1 . 7 3}) ; \mathbf{9 . 3} \% \\
\text { AA: } 1.30(0.73-2.29) \\
\text { CA/AA: } \mathbf{1 . 3 4}(\mathbf{1 . 0 5}-\mathbf{1 . 7 2}) ; \\
\mathbf{1 0 . 1} \%\end{array}$ & {$[28]$} \\
\hline
\end{tabular}

$n$ : number of cases; OR: odds ratio; 95\% CI: 95\% confidence interval; CIN: cervical intraepithelial neoplasia; PAF: population attributable fraction.

${ }^{a}$ Nucleotide variation and dbSNP reference number.

${ }^{\mathrm{b}} \mathrm{OR}$ relative to major allele or major allele homozygotes.

${ }^{\mathrm{c}} \mathrm{PAF}$ listed if $\mathrm{OR}>1.00$.

${ }^{\mathrm{d}}$ Significant associations listed in bold.

TABLE 3: Overview of polymorphisms in gene encoding chemokines and association with cervical neoplasia risk.

\begin{tabular}{|c|c|c|c|c|c|c|c|}
\hline Gene & Polymorphism $^{\mathrm{a}}$ & Cohort & Cases $(n)$ & Population & Distribution & $\begin{array}{c}\text { Risk (OR, 95\% CI); } \\
\text { PAF }^{\mathrm{b}, \mathrm{c}, \mathrm{d}}\end{array}$ & Reference \\
\hline \multirow{3}{*}{$\begin{array}{l}\text { CXCL12 } \\
(S D F-1)\end{array}$} & \multirow{3}{*}{$\mathrm{G}>\mathrm{A}$ rs266085 } & \multirow{3}{*}{ Cervical cancer } & & & Alleles & A: $0.74(0.56-0.98)$ & \multirow[b]{2}{*}[29]{} \\
\hline & & & 917 & American & $\begin{array}{c}\text { Haplotypes } \\
\text { (rs266085/ } \\
\text { rs17885289G }>A / \\
\text { rs266093C }>\mathrm{G})\end{array}$ & A/A/C: $0.69(0.54-0.89)$ & \\
\hline & & & 348 & $\begin{array}{c}\text { Han } \\
\text { Chinese }\end{array}$ & Alleles & A: 1.41 (1.14-1.74); 17.1\% & {$[30]$} \\
\hline
\end{tabular}

$n$ : number of cases; OR: odds ratio; $95 \% \mathrm{CI}$ : 95\% confidence interval.

${ }^{a}$ Nucleotide variation and dbSNP reference number.

${ }^{\mathrm{b}} \mathrm{OR}$ relative to major allele or major allele homozygotes.

${ }^{\mathrm{c}} \mathrm{PAF}$ listed if OR $>1.00$.

${ }^{\mathrm{d}}$ Significant associations listed in bold. 
Interleukin-10 (IL-10) has both immunosuppressive and antiangiogenic effects and may therefore exert both tumourpromoting and antitumour effects [79, 80]. Associations with both increased and decreased IL-10 levels in cervical cancer have been shown in different studies [81]. The IL10 c. $-1082 \mathrm{~A}>\mathrm{G}$ polymorphism has been shown to influence levels of IL-10 production, with major allele homozygosity being associated with low IL-10 levels, heterozygosity with intermediate levels, and minor allele homozygosity with high levels [82]. Several studies have investigated this SNP in cervical carcinoma with varying and often contradictory results $[23,24,26,28,83-86]$. A recent meta-analysis with pooled data from 1498 cases and 1608 controls showed no significant association of this SNP with cervical carcinoma risk [25]. However, the same meta-analysis did find a significant association for another IL10 promotor SNP (c.-592C >A), with occurrence of the minor allele associated with increased cervical cancer risk, especially among Asian patients [25]. This association was also found in Mexican, Dutch, and Indian studies, as well as a more recent meta-analysis [16, 2628]. The seemingly contradictory effects of IL-10 on carcinogenesis might have different implications for HPV infection and cervical cancer, given that angiogenesis is likely to be more important in later development of malignant tumours than in viral infection and persistence [87]. It is therefore possible that the heterogeneous effect of IL10 polymorphisms in HPV and cervical cancer might be tied to the stage of lesions.

3.3. Chemokines. To date, polymorphisms in only one chemokine gene, CXCL12, have been reported in relation to cervical carcinoma. Chemokine CXCL12, also known as stromal-cell derived factor 1 (SDF-1), directs leucocyte migration and, through interactions with its receptor CXCR4 [88], it is also involved in the regulation of metastatic behaviour of certain tumour cell lines $[89,90]$. One North American study investigated the role of several CXCL12 SNPs in cervical cancer and identified one intronic SNP (rs266085), where the minor allele was associated with a decreased risk of cervical cancer. Using haplotype interaction analysis, this group identified a combination of three SNPs (rs266085, rs266093, and rs17885289), which was associated with cervical cancer risk [29]. The location of these SNPs in the 5' UTR (rs17885289), second intron (rs266085), and $3^{\prime}$ UTR (rs266093) regions of the CXCL12 gene is consistent with several possible aetiologic mechanisms for the identified association with cervical carcinoma, including alternative splicing and regulation of CXCL12 induction [91-93]. In contrast to this study, a separate study among Han Chinese women demonstrated a significant association of the rs266085 minor allele with higher risk of cervical cancer [30]. Stronger CXCL12 induction may have similar consequences as those seen in patients with mutations in the CXCR4 gene, which lead to increased cellular responsiveness to CXCL12, yielding a rare syndrome characterised by immune deficits and extensive HPV-induced lesions $[94,95]$.

\section{Receptors}

Receptors bind a wide variety of ligands, including cytokines, costimulation transmembrane proteins, and pathogen-associated molecular patterns (PAMPs). Due to the different ligands and functions associated with them, many different receptors have been found to be associated with antitumour immunity. Genetic variation in the corresponding genes has been found to be strongly associated with HPV infection and subsequent cervical carcinoma.

The cell-surface FAS receptor induces apoptosis after binding by the FAS ligand (FASL) [96]. Two SNPs in the promotor region of the FAS gene have been identified: c.1377G >A and c.-670G >A (Table 4). These SNPs disrupt Sp1 and STAT1 transcription factor binding sites, thus diminishing promotor activity and leading to FAS downregulation. Both SNPs are associated with several diseases, including acute myeloid leukaemia and systemic lupus erythematosus $[97,98]$. Polymorphism at c.-670G $>$ A has been found to be associated with cervical carcinogenesis, with the minor allele associated with higher risk of high-grade CIN and cervical cancer $[31,32]$. Other studies have shown varying associations of FAS c.-670G>A with cervical carcinogenesis. A recent meta-analysis showed no significant association of this SNP with cervical cancer either in the overall population or in ethnical subgroups [33]. The c.-1377A $>$ G SNP does not seem to be associated with cervical neoplasia individually [35] but has been shown to strengthen the effect of c.-670G>A [31].

One SNP in the FASL gene has been investigated for association with cervical cancer (Table 4). FASL c.-844T>C lies within a putative binding motif for CAAT/enhancerbinding protein $(\mathrm{C} / \mathrm{EBP} \beta)$ and the two resulting alleles have different affinities for $\mathrm{C} / \mathrm{EBP} \beta$. This SNP has been demonstrated to have functional consequences: minor allele homozygosity has been linked to increased FASL expression and alteration of FASL-mediated signalling in lymphocytes [99]. Consequently, one study has demonstrated an association with cervical carcinoma risk [34]. However, in a recent meta-analysis, the FASL c.-844T>C SNP was not associated with cervical carcinoma risk [35].

4.1. Toll-Like Receptors (Table 5). Toll-like receptors (TLRs) are transmembrane proteins that recognise pathogenassociated molecular patterns (PAMPs), the conserved structural motifs in pathogenic organisms [100]. TLRs are normally anchored in the plasma membrane but can also be present in intracellular membrane compartments, such as endosomes or lysosomes [100].

Toll-like receptor 2 (TLR2) is a pattern recognition receptor that senses the presence of bacterial lipoproteins and other components of bacteria and fungi [101]. However, there is mounting evidence that points to its putative role in sensing viral pathogens as well $[102,103]$. Accordingly, the TLR2 c.+613T>C SNP showed association with cervical cancer in a Costa Rican population [36].

TLR4 plays an important role in recognising lipopolysaccharide molecules present in Gram-negative bacteria; however, as in the case of TLR2, recognition of viruses has also been implicated [104]. Heterozygosity at TLR4 c.+936C > T 
TABLE 4: Overview of polymorphism in FAS and FASL genes encoding receptors and association with cervical neoplasia risk.

\begin{tabular}{|c|c|c|c|c|c|c|c|}
\hline Gene & Polymorphism $^{\mathrm{a}}$ & Cohort & Cases $(n)$ & Population & Distribution & $\begin{array}{c}\text { Risk (OR, 95\% CI); } \\
\text { PAF }^{\mathrm{b}, \mathrm{c}, \mathrm{d}}\end{array}$ & Reference \\
\hline \multirow{5}{*}{ FAS } & \multirow{5}{*}{$\begin{array}{l}\text { c. }-670 \mathrm{G}>\mathrm{A} \\
(\mathrm{rs} 1800682)\end{array}$} & \multirow{3}{*}{$\begin{array}{c}\text { CIN } \\
\text { Cervical cancer }\end{array}$} & \multirow{3}{*}{$\begin{array}{l}143 \\
175\end{array}$} & \multirow{3}{*}{$\begin{array}{l}\text { Han } \\
\text { Chinese }\end{array}$} & Alleles & A: $1.26(1.01-1.57) ; 12.4 \%$ & \multirow[b]{3}{*}[31]{} \\
\hline & & & & & Genotypes & $\begin{array}{l}\text { GA: } 1.11(0.60-2.02) \\
\text { AA: } 1.83(0.97-3.44)\end{array}$ & \\
\hline & & & & & $\begin{array}{l}\text { Haplotypes } \\
(F A S \text { c. }-670 / \\
\text { c. }-1377 A>G)\end{array}$ & $\begin{array}{c}\text { G/G: } 1.38(0.80-2.37) \\
\text { A/A: } 3.05(\mathbf{1 . 2 8}-\mathbf{7 . 3 0}) \\
\mathbf{1 1 . 3} \% \\
\text { A/G: } 1.27(1.00-1.60)\end{array}$ & \\
\hline & & $\begin{array}{c}\text { CIN I } \\
\text { CIN II/III } \\
\text { Cervical cancer }\end{array}$ & $\begin{array}{l}104 \\
131 \\
176\end{array}$ & Taiwanese & Alleles & $\begin{array}{c}\text { CIN I } \\
\text { A: } 1.1(0.8-1.6) \\
\text { CIN II/III } \\
\text { A: } 1.1(0.8-1.6) \\
\text { Cervical cancer } \\
\text { A: } \mathbf{1 . 5}(\mathbf{1 . 1}-\mathbf{2 . 0}) ; \mathbf{2 0 . 5} \%\end{array}$ & {$[32]$} \\
\hline & & Cervical cancer & 2317 & Varied & Alleles & A: $0.97(0.84-1.11)$ & {$[33]$} \\
\hline \multirow[t]{2}{*}{ FASL } & \multirow[t]{2}{*}{$\begin{array}{l}\text { c. }-844 \mathrm{~T}>\mathrm{C} \\
(\mathrm{rs} 736110)\end{array}$} & \multirow[t]{2}{*}{ Cervical cancer } & 314 & Chinese & Genotypes & $\begin{array}{c}\text { TC: } 1.68(0.78-3.66) \\
\text { CC: } 3.05(1.43-6.52) \text {; } \\
41.3 \%\end{array}$ & {$[34]$} \\
\hline & & & 2485 & Varied & Alleles & C: $1.12(0.91-1.36)$ & [35] \\
\hline
\end{tabular}

$n$ : number of cases; OR: odds ratio; 95\% CI: 95\% confidence interval; CIN: cervical intraepithelial neoplasia; PAF: population attributable fraction.

${ }^{a}$ Nucleotide variation and dbSNP reference number.

${ }^{\mathrm{b}} \mathrm{OR}$ relative to major allele or major allele homozygotes.

${ }^{\mathrm{c}} \mathrm{PAF}$ listed if $\mathrm{OR}>1.00$.

${ }^{\mathrm{d}}$ Significant associations listed in bold.

polymorphism was associated with stage II cervical cancer in a North Indian population [37].

Toll-like receptor 9 (TLR9) recognises nonmethylated CpG DNA sequences, ubiquitous in bacterial and viral genomes, for instance, HPV16. Viral oncoproteins E6 and E7 block the expression of this receptor, thereby contributing to HPV immune evasion [105]. TLR9 polymorphisms may therefore influence HPV persistence and cervical carcinogenesis. The TLR9 c. $+2848 \mathrm{G}>\mathrm{A}$ SNP was shown to be associated with risk of cervical carcinoma, with the minor allele associated with an increased cancer risk among Chinese Han women [38]. Similar results were obtained in a large Polish study [39]. Similarly, the TLR9 c.-1486T >C SNP has been associated with cervical cancer risk in various studies $[39,40]$.

\section{Antigen-Processing Machinery}

The antigen-processing machinery (APM) is responsible for the generation, trimming, transport, and loading of peptides derived from intracellular proteins to be presented by molecules of the human leucocyte antigen (HLA) family to cytotoxic T lymphocytes [106]. The main components of the APM are low molecular-weight proteins (LMP) 2 and 7, involved in generation of peptides from intracellular proteins, transporter associated with antigen presentations (TAP) 1 and 2, involved in transporting peptides from the cytosol to the endoplasmic reticulum, where peptides undergo further trimming by endoplasmic reticulum aminopeptidase associated with antigen presentations (ERAP) 1 and 2, and chaperone molecules including tapasin, calnexin, calreticulin, and
Erp57, which are responsible for loading of the peptides onto empty HLA class 1 molecules. As both viral infection and malignant transformation lead to the occurrence of aberrant intracellular proteins, the APM is hypothesised to be an important mechanism of recognition and lysis of virally infected and neoplastic transformed cells. Correspondingly, polymorphisms in various genes encoding APM components have demonstrated association with increased cervical carcinoma risk as well as with worse clinical outcome (Table 6). The most probable explanation for this is that genetic variation in certain APM components may ultimately lead to alterations in the immunogenicity of the repertoire of peptides presented by HLA class 1 molecules. In particular, SNPs in the LMP7, TAP2, and ERAP1 have been found to be associated with cervical carcinoma risk, lymph node metastases, and overall survival, both individually and in specific haplotype configurations [41, 45]. Though similar gene and haplotype associations have been found in several populations, including Dutch, Indonesian, Austrian Caucasian, North Indian, and North American, the actual genes and gene combinations involved differ greatly between the various populations [42-44, 107].

\section{Discussion}

There is a great diversity of immunogenetic associations with HPV infection, persistence, and cervical neoplastic transformation, based on the overwhelming body of continuously growing data. Contradicting results indicated by different studies attest to the complexity of the topic. Moreover, the wide variation in sample size amongst the various studies can 
TABLE 5: Overview of polymorphisms in toll-like receptor genes encoding receptors and association with cervical neoplasia risk.

\begin{tabular}{|c|c|c|c|c|c|c|c|}
\hline Gene & Polymorphism $^{\mathrm{a}}$ & Cohort & Cases $(n)$ & Population & Distribution & $\begin{array}{c}\text { Risk (OR, 95\% CI); } \\
\text { PAF }^{\mathrm{b}, \mathrm{c}, \mathrm{d}}\end{array}$ & Reference \\
\hline TLR2 & $\begin{array}{l}\text { c. }+613 \mathrm{~T}>\mathrm{C} \\
(\mathrm{rs} 3804100)\end{array}$ & $\begin{array}{c}\text { CIN III } \\
\text { Cervical cancer }\end{array}$ & 470 & $\begin{array}{l}\text { Costa } \\
\text { Rican }\end{array}$ & Genotypes & $\begin{array}{c}\text { TC: } \mathbf{0 . 6 1}(\mathbf{0 . 3 9 - 0 . 9 5 )} \\
\text { CC: } 0.56(0.09-3.50) \\
\text { TC/CC: } \mathbf{0 . 6 1}(\mathbf{0 . 4 0 - 0 . 9 3 )}\end{array}$ & {$[36]$} \\
\hline TLR4 & $\begin{array}{l}\text { c.+936C>T } \\
(\mathrm{rs} 4986791)\end{array}$ & Cervical cancer & 150 & $\begin{array}{l}\text { North } \\
\text { Indian }\end{array}$ & Genotypes & $\begin{array}{c}\text { Overall } \\
\text { CT: } 1.50(0.72-2.92) \\
\text { TT: } 2.20(0.20-24.76) \\
\text { Stage II } \\
\text { CT: } \mathbf{2 . 5 0}(\mathbf{1 . 0 3}-\mathbf{6 . 1 2}) \text {; } \\
\mathbf{1 2 . 5} \% \\
\text { TT: - } \\
\text { Stage III } \\
\text { CT: } 1.30(0.54-2.97) \\
\text { TT: } 4.20(0.37-47.64)\end{array}$ & [37] \\
\hline \multirow{3}{*}{ TLR9 } & \multirow{3}{*}{$\begin{array}{c}\text { c. }+2848 \mathrm{G}>\mathrm{A} \\
(\mathrm{rs} 382140)\end{array}$} & \multirow{3}{*}{ Cervical cancer } & & & Alleles & $\begin{array}{c}\text { A: } 7.001(2.422-20.23) ; \\
10.7 \%\end{array}$ & \\
\hline & & & 120 & $\begin{array}{c}\text { Chinese } \\
\text { Han }\end{array}$ & Genotypes & $\begin{array}{c}\text { GA: } 6.929(1.534-33.30) \text {; } \\
10.0 \% \\
\text { AA: } 7.918(1.797-64.52) \text {; } \\
5.9 \% \\
\text { GA/AA: } 7.259 \\
(2.104-25.05) ; 15.8 \%\end{array}$ & [38] \\
\hline & & & 426 & Polish & Genotypes & $\begin{array}{c}\text { GA: } 1.443(1.019-2.043) \text {; } \\
\text { 16.6\% } \\
\text { AA: } 1.237(1.016-1.507) ; \\
\mathbf{5 . 0} \% \\
\text { GA/AA: } 1.345 \\
(0.976-1.855)\end{array}$ & [39] \\
\hline \multirow[b]{2}{*}{ TLR9 } & \multirow[b]{2}{*}{$\begin{array}{c}\text { c. }-1486 \mathrm{~T}>\mathrm{C} \\
(\mathrm{rs} 187084)\end{array}$} & \multirow[b]{2}{*}{ Cervical cancer } & 712 & Chinese & Genotypes & $\begin{array}{c}\text { TC: } 1.28(1.01-1.62) \\
\text { TC/CC: } 1.24(1.01-1.53)\end{array}$ & {$[40]$} \\
\hline & & & 426 & Polish & Genotypes & $\begin{array}{c}\text { TC: } 1.371(1.021-1.842) \text {; } \\
13.0 \% \\
\text { CC: } 1.300(1.016-1.507) ; \\
4.4 \% \\
\text { TC/CC: } 1.448 \\
(1.099-1.908) ; 20.7 \%\end{array}$ & {$[39]$} \\
\hline
\end{tabular}

$n$ : number of cases; OR: odds ratio; $95 \%$ CI: $95 \%$ confidence interval; CIN: cervical intraepithelial neoplasia; PAF: population attributable fraction.

${ }^{a}$ Nucleotide variation and dbSNP reference number.

${ }^{\mathrm{b}} \mathrm{OR}$ relative to major allele or major allele homozygotes.

${ }^{\mathrm{c}} \mathrm{PAF}$ listed if OR $>1.00$.

${ }^{\mathrm{d}}$ Significant associations listed in bold.

lead to underestimation of the actual strength of association of particular loci with disease [108]. Multiple gene-gene and gene-environment interactions ought to be inspected on par, in order to gain a comprehensive, systematic insight into the molecular network underlying the aetiology of HPV persistence and cervical cancer. However, as is the case with low-penetrance alleles, we can only speak in terms of attributable risks. For a considerable number of genes listed in this review, contributions of each polymorphism or even a haplotype to a disease are often modest. Just as HPV infection alone is not sufficient to develop cervical dysplasia or cervical carcinoma, one particular genotype or haplotype is not likely to individually cause disease. A possibly more plausible scenario is that in which, following infection with an oncogenic HPV type and initial malignant transformation of cervical epithelial cells, certain SNPs in APM components may lead to a less immunogenic peptide repertoire to be presented to local immune cells. The presentation of these peptides may be further influenced by polymorphisms in HLA genes. The resulting immune response is then further attenuated by underlying SNPs in cytokine genes and receptor/KIR genes, which lead to a less effective overall local immune response. The end result of all these factors may then be further development and progression of malignant cells, ultimately leading to high-stage cervical carcinoma. This hypothesis is based on an interplay between host genomic factors, environmental factors, and HPV-related factors, which may explain the sometimes contradictory associations found for genes among different populations.

An emerging field in genetic association studies is that of haplotype interaction analysis, which investigates the association of specific SNP combinations (often spanning 
TABLE 6: Overview of polymorphisms in genes encoding antigen processing machinery components and association with cervical neoplasia risk/survival.

\begin{tabular}{|c|c|c|c|c|c|c|c|}
\hline Gene & Polymorphism $^{\mathrm{a}}$ & Cohort & $\begin{array}{c}\text { Cases } \\
(n)\end{array}$ & Population & Distribution & $\begin{array}{c}\text { Risk (OR, 95\% CI); } \\
\text { PAF }^{\mathrm{b}, c, d}\end{array}$ & Reference \\
\hline \multirow{5}{*}{ ERAP1 } & \multirow{2}{*}{$\begin{array}{c}E R A P 1-127 \\
(\mathrm{c} .+380 \mathrm{G}>\mathrm{C} \\
\mathrm{rs} 26653)\end{array}$} & \multirow[t]{2}{*}{ Cervical cancer } & 127 & Dutch & Alleles & $\begin{array}{c}\text { C: } 1.652(1.106-2.467) ; \\
12.4 \%\end{array}$ & {$[41]$} \\
\hline & & & 98 & Javanese & Alleles & C: $0.656(0.437-0.985)$ & {$[42]$} \\
\hline & \multirow{2}{*}{$\begin{array}{l}\text { ERAP1-730 } \\
(\mathrm{c} .+2188 \mathrm{C}>\mathrm{G} ; \\
\quad \mathrm{rs} 27044)\end{array}$} & \multirow[t]{2}{*}{ Cervical cancer } & 127 & Dutch & Alleles & $\begin{array}{c}\text { G: } 1.685(1.136-2.500) ; \\
13.6 \%\end{array}$ & {$[41]$} \\
\hline & & & 98 & Javanese & Alleles & G: $0.644(0.431-0.962)$ & {$[42]$} \\
\hline & $\begin{array}{c}\text { ERAP1-528 } \\
\text { (c.+1583C>T; } \\
\text { rs30187) }\end{array}$ & Cervical cancer & 98 & Javanese & Alleles & T: $0.643(0.429-0.964)$ & {$[42]$} \\
\hline$L M P 7$ & $\begin{array}{l}L M P 7-145 \\
\text { (c.145C>A; } \\
\text { rs2071543) }\end{array}$ & Cervical cancer & 127 & Dutch & Alleles & A: $0.565(0.346-0.920)$ & {$[41]$} \\
\hline TAP1 & $\begin{array}{c}\text { TAP1-333 } \\
(\text { c. }+1177 \mathrm{~A}>\mathrm{G} \\
\text { rs4148880) }\end{array}$ & CIN III & 114 & American & Genotypes & AG/GG: $0.28(0.10-0.80)$ & {$[43]$} \\
\hline TAP1 & $\begin{array}{c}\text { TAP1-637 } \\
(\mathrm{A}>\mathrm{G} ; \mathrm{rs} 1135216)\end{array}$ & CIN III & 114 & American & Genotypes & AG/GG: $0.27(0.1-0.7)$ & {$[43]$} \\
\hline \multirow[b]{2}{*}{ TAP2 } & TAP2-651 & \multirow[b]{2}{*}{ Cervical cancer } & 127 & Dutch & Alleles & A: $0.481(0.246-0.942)$ & {$[41]$} \\
\hline & $\begin{array}{l}(\mathrm{c} .+1951 \mathrm{C}>\mathrm{A} \\
\text { rs } 4148876)\end{array}$ & & 103 & Balinese & Alleles & $\begin{array}{c}\text { A: } 3.837 \text { (2.379-6.189); } \\
47.2 \%\end{array}$ & {$[42]$} \\
\hline TAP2 & $\begin{array}{c}\text { TAP2-379 } \\
\text { (c.1135G }>\text { A; } \\
\text { rs4148873) }\end{array}$ & $\mathrm{CIN}$ & 616 & Caucasian & Alleles & A: $0.5(0.4-0.8)$ & {$[44]$} \\
\hline \multirow{3}{*}{$\begin{array}{l}\text { Various APM } \\
\text { gene } \\
\text { combinations }\end{array}$} & $\begin{array}{c}\text { ERAP1-127(G>C)/ } \\
\text { ERAP1-730 }(\mathrm{C}>\mathrm{G}) / \\
\text { TAP2-651 }(\mathrm{C}>\mathrm{A}) / \\
L M P 7-145(\mathrm{C}>\mathrm{A})\end{array}$ & Cervical cancer & 127 & Dutch & Haplotypes & $\begin{array}{c}\mathrm{C} / \mathrm{G} / \mathrm{C} / \mathrm{C}: 3.024 \\
(1.656-5.519) ; 11.6 \%\end{array}$ & {$[41]$} \\
\hline & $\begin{array}{c}\text { ERAP1-575(C>T)/ } \\
\text { TAP2-379(G>A)/ } \\
\text { TAP2-651 }(\mathrm{C}>\mathrm{A})\end{array}$ & Cervical cancer & 98 & Javanese & Haplotypes & $\begin{array}{c}\mathrm{T} / \mathrm{C} / \mathrm{G}: 3.36(0.98-11.56) ; \\
3.9 \%\end{array}$ & {$[42]$} \\
\hline & $\begin{array}{l}\text { ERAP1-56(G>A)/ } \\
\text { ERAP1-127 }(\mathrm{G}>\mathrm{C})\end{array}$ & $\begin{array}{c}\text { Cervical cancer } \\
\text { survival } \\
\end{array}$ & 75 & Dutch & Haplotypes & $\begin{array}{c}\text { G/C heterozygotes: } 0.219 \\
(0.065-0.731)^{\mathrm{e}}\end{array}$ & {$[45]$} \\
\hline
\end{tabular}

multiple chromosomes) with particular diseases [109]. This is based on the assumption that where individual SNPs may exert a (weak) influence on disease traits, the combination of particular alleles at these loci may bear a stronger association. Until now, all such analyses have been limited to genes from the same category (e.g., haplotypes spanning only APM component genes). The logical next step would be to investigate combinations of a larger spectrum of gene variants (e.g., haplotypes spanning APM component genes, combined with cytokine and receptor genes).

The increasingly popular genome-wide association study (GWAS) approach for the purpose of identifying polymorphisms of interest appears promising for the purpose of elucidating the susceptibility to persistent HPV infection as well as progression of cervical neoplasia $[53,110]$. Also, the emergence of integrative sciences such as systems biology and immunoinformatics appears to be an encouraging approach that could help explain these interactions and provide a full understanding of the aetiology of these diseases [111, 112]. Understanding the immunogenetic networks that underlie complex diseases such as cancer would hopefully bring personalised prevention, diagnosis, and treatment closer to their successful implementation into the healthcare system. It would be interesting to see whether this can be accomplished by incorporating these factors with other biomarkers most predictive of cervical lesions, $M A L / C A D M 1$ methylation pattern, p16INK-4a/Ki-67 dual immunostaining, and viral integration [113]. These markers appear most promising for the usage in successful triage of hrHPV-positive women for the purpose of successful screening for high-grade lesions. 
Aside from the potential to alter diagnostic risk assessment, detailed insights into the roles of immunogenetic factors in HPV infection and cervical cancer can contribute to other levels of prevention as well as therapeutics. Combining knowledge of a person's HPV status with immunogenetic factors (both in the genes described in this review and in other immunologically important genes, e.g., HLA) could enable the development of host-directed treatment based on a person's immunogenetic profile, which may lead to a more effective cure or remission with minimised side effects. Developing a therapeutic HPV vaccine would provide novel means of treatment for individuals already infected with hrHPV or suffering from related diseases [114]. Elucidating the precise role of immunogenetics in HPV infection and cervical neoplasia is a prerequisite for making these advances.

Ultimately, by combining data regarding HPV infection and distribution with host genomic data, it may be possible to make individual "predictions" not just of the risk of developing cervical cancer and its progression but also of the efficacy of therapies and, equally important, the efficacy of anti-HPV vaccination programmes, all of which will ultimately facilitate the development of tailor-made, personalised interventions.

\section{Competing Interests}

The authors declare that they have no conflict of interests.

\section{Authors' Contributions}

Akash M. Mehta and Merel Mooij contributed equally to this work.

\section{References}

[1] J. G. Baseman and L. A. Koutsky, “The epidemiology of human papillomavirus infections," Journal of Clinical Virology, vol. 32, supplement 1, pp. S16-S24, 2005.

[2] J. M. Torpy, A. E. Burke, and R. M. Glass, "JAMA patient page. Human papillomavirus infection," JAMA, vol. 297, no. 8, article no. 912, 2007.

[3] W. I. Al-Daraji and J. H. F. Smith, "Infection and cervical neoplasia: facts and fiction," International Journal of Clinical and Experimental Pathology, vol. 2, no. 1, pp. 48-64, 2009.

[4] B. Cao, X. Tian, Y. Li et al., "LMP7/TAP2 gene polymorphisms and HPV infection in esophageal carcinoma patients from a high incidence area in China," Carcinogenesis, vol. 26, no. 7, pp. 1280-1284, 2005.

[5] L. Bruni, M. Diaz, X. Castellsagué, E. Ferrer, F. X. Bosch, and S. De Sanjosé, "Cervical human papillomavirus prevalence in 5 continents: meta-analysis of 1 million women with normal cytological findings," Journal of Infectious Diseases, vol. 202, no. 12, pp. 1789-1799, 2010.

[6] F. X. Bosch and S. De Sanjosé, "The epidemiology of human papillomavirus infection and cervical cancer," Disease Markers, vol. 23, no. 4, pp. 213-227, 2007.

[7] S. Kanodia, L. M. Fahey, and W. M. Kast, "Mechanisms used by human papillomaviruses to escape the host immune response," Current Cancer Drug Targets, vol. 7, no. 1, pp. 79-89, 2007.

[8] J. R. Cerhan, S. M. Ansell, Z. S. Fredericksen et al., "Genetic variation in 1253 immune and inflammation genes and risk of
non-Hodgkin lymphoma," Blood, vol. 110, no. 13, pp. 4455-4463, 2007.

[9] M. G. Netea, C. Wijmenga, and L. A. J. O’Neill, “Genetic variation in Toll-like receptors and disease susceptibility," Nature Immunology, vol. 13, no. 6, pp. 535-542, 2012.

[10] G. Lettre and J. D. Rioux, "Autoimmune diseases: insights from genome-wide association studies," Human Molecular Genetics, vol. 17, no. 2, pp. R116-R121, 2008.

[11] S. Hardikar, L. G. Johnson, M. Malkki et al., "A populationbased case-control study of genetic variation in cytokine genes associated with risk of cervical and vulvar cancers," Gynecologic Oncology, vol. 139, no. 1, pp. 90-96, 2015.

[12] S. Kang, J. W. Kim, N. H. Park et al., "Interleukin-1 beta-511 polymorphism and risk of cervical cancer," Journal of Korean Medical Science, vol. 22, no. 1, pp. 110-113, 2007.

[13] H. Singh, R. Sachan, H. Goel, and B. Mittal, "Genetic variants of interleukin-1RN and interleukin- $1 \beta$ genes and risk of cervical cancer," BJOG: An International Journal of Obstetrics and Gynaecology, vol. 115, no. 5, pp. 633-638, 2008.

[14] N. Qian, X. Chen, S. Han et al., "Circulating IL-1 $\beta$ levels, polymorphisms of IL-1B, and risk of cervical cancer in Chinese women," Journal of Cancer Research and Clinical Oncology, vol. 136, no. 5, pp. 709-716, 2010.

[15] M. A. Al-Tahhan, R. L. Etewa, and M. M. El Behery, "Association between circulating interleukin-1 beta (IL-1 $\beta$ ) levels and IL$1 \beta$ C-511T polymorphism with cervical cancer risk in Egyptian women," Molecular and Cellular Biochemistry, vol. 353, no. 1-2, pp. 159-165, 2011.

[16] X. Zhang, L. Zhang, C. Tian, L. Yang, and Z. Wang, "Genetic variants and risk of cervical cancer: epidemiological evidence, meta-analysis and research review," BJOG : an international journal of obstetrics and gynaecology, vol. 121, no. 6, pp. 664674, 2014.

[17] I. Duarte, A. Santos, H. Sousa et al., "G-308A TNF- $\alpha$ polymorphism is associated with an increased risk of invasive cervical cancer," Biochemical and Biophysical Research Communications, vol. 334, no. 2, pp. 588-592, 2005.

[18] I. Kohaar, N. Thakur, S. Salhan et al., "TNFalpha-308G/A polymorphism as a risk factor for HPV associated cervical cancer in Indian population," Cellular Oncology, vol. 29, no. 3, pp. 249-256, 2007.

[19] M. K. K. Tamandani, R. C. Sobti, M. Shekari, M. Mukesh, and V. Suri, "Expression and polimorphism of IFN- $\gamma$ gene in patients with cervical cancer," Experimental Oncology, vol. 30, no. 3, pp. 224-229, 2008.

[20] R. Gangwar, S. Pandey, and R. D. Mittal, "Association of interferon- $\gamma+874 \mathrm{~A}$ polymorphism with the risk of developing cervical cancer in north-Indian population," BJOG: An International Journal of Obstetrics and Gynaecology, vol. 116, no. 12, pp. 1671-1677, 2009.

[21] Q. Wang, C. Zhang, S. Walayat, H. W. Chen, and Y. Wang, "Association between cytokine gene polymorphisms and cervical cancer in a Chinese population," European Journal of Obstetrics and Gynecology and Reproductive Biology, vol. 158, no. 2, pp. 330-333, 2011.

[22] Y. Sun, Y. Lu, Q. Pen et al., "Interferon gamma +874 T/A polymorphism increases the risk of cervical cancer: evidence from a meta-analysis," Tumor Biology, vol. 36, no. 6, pp. 45554564, 2015.

[23] K. Matsumoto, A. Oki, T. Satoh et al., "Interleukin-10-1082 gene polymorphism and susceptibility to cervical cancer among 
Japanese women," Japanese Journal of Clinical Oncology, vol. 40, no. 11, pp. 1113-1116, 2010.

[24] G. A. Stanczuk, E. N. Sibanda, C. Perrey et al., "Cancer of the uterine cervix may be significantly associated with a gene polymorphism coding for increased IL-10 production," International Journal of Cancer, vol. 94, no. 6, pp. 792-794, 2001.

[25] J. Ni, Y. Ye, F. Teng, and Q. Wu, "Interleukin 10 polymorphisms and cervical cancer risk: a meta-analysis," International Journal of Gynecological Cancer, vol. 23, no. 1, pp. 126-133, 2013.

[26] P. Singhal, A. Kumar, S. Bharadwaj, S. Hussain, and M. Bharadwaj, "Association of IL-10 GTC haplotype with serum level and HPV infection in the development of cervical carcinoma," Tumor Biology, vol. 36, no. 4, pp. 2287-2298, 2015.

[27] K. Torres-Poveda, A. I. Burguete-García, M. Cruz et al., “The SNP at -592 of human IL-10 gene is associated with serum IL10 levels and increased risk for human papillomavirus cervical lesion development," Infectious Agents and Cancer, vol. 7, no. 1, article 32, 2012

[28] M. Zoodsma, I. M. Nolte, M. Schipper et al., "Interleukin-10 and Fas polymorphisms and susceptibility for (pre)neoplastic cervical disease," International Journal of Gynecological Cancer, vol. 15, no. 6, pp. 282-290, 2005.

[29] S. N. Maley, S. M. Schwartz, L. G. Johnson et al., "Genetic variation in CXCL12 and risk of cervical carcinoma: a populationbased case-control study," International Journal of Immunogenetics, vol. 36, no. 6, pp. 367-375, 2009.

[30] G. Yin, T. Zhu, J. Li, A. Wu, J. Liang, and Y. Zhi, "CXCL12 rs266085 and TNF-alpha rs1799724 polymorphisms and susceptibility to cervical cancer in a Chinese population," International Journal of Clinical and Experimental Pathology, vol. 8, no. 5, pp. 5768-5774, 2015.

[31] H.-C. Lai, W.-Y. Lin, Y.-W. Lin et al., "Genetic polymorphisms of FAS and FASL (CD95/CD95L) genes in cervical carcinogenesis: an analysis of haplotype and gene-gene interaction," Gynecologic Oncology, vol. 99, no. 1, pp. 113-118, 2005.

[32] H.-C. Lai, H.-K. Sytwu, C.-A. Sun et al., "Single nucleotide polymorphism at Fas promoter is associated with cervical carcinogenesis," International Journal of Cancer, vol. 103, no. 2, pp. 221-225, 2003.

[33] J. Shen and N.-X. Sun, "Association between FAS A670G polymorphism and susceptibility to cervical cancer: evidence from a meta-analysis," Tumor Biology, vol. 34, no. 6, pp. 34433448, 2013.

[34] T. Sun, Y. Zhou, H. Li et al., "FASL -844C polymorphism is associated with increased activation-induced $\mathrm{T}$ cell death and risk of cervical cancer," The Journal of Experimental Medicine, vol. 202, no. 7, pp. 967-974, 2005.

[35] G.-Q. Wang, L. Bao, X.-X. Zhao, J. Zhang, and K.-J. Nan, "Associations between Fas/FasL polymorphisms and susceptibility to cervical cancer: a meta-analysis," Tumor Biology, vol. 35, no. 5, pp. 4107-4112, 2014.

[36] S. S. Wang, M. C. Bratti, A. C. Rodríguez et al., "Common variants in immune and DNA repair genes and risk for human papillomavirus persistence and progression to cervical cancer," Journal of Infectious Diseases, vol. 199, no. 1, pp. 20-30, 2009.

[37] S. Pandey, R. D. Mittal, M. Srivastava et al., "Impact of Toll-like receptors [TLR] 2 (-196 to $-174 \mathrm{del}$ ) and TLR 4 (Asp299Gly, Thr399Ile) in cervical cancer susceptibility in North Indian women," Gynecologic Oncology, vol. 114, no. 3, pp. 501-505, 2009.

[38] Z.-Z. Lai, Ni-Zhang, X.-L. Pan, and L. Song, "Toll-like receptor 9 (TLR9) gene polymorphisms associated with increased susceptibility of human papillomavirus-16 infection in patients with cervical cancer," Journal of International Medical Research, vol. 41, no. 4, pp. 1027-1036, 2013.

[39] A. Roszak, M. Lianeri, A. Sowińska, and P. P. Jagodziński, "Involvement of Toll-like receptor 9 polymorphism in cervical cancer development," Molecular Biology Reports, vol. 39, no. 8, pp. 8425-8430, 2012.

[40] X. Chen, S. Wang, L. Liu et al., "A genetic variant in the promoter region of toll-like receptor 9 and cervical cancer susceptibility," DNA and Cell Biology, vol. 31, no. 5, pp. 766-771, 2012.

[41] A. M. Mehta, E. S. Jordanova, T. van Wezel et al., "Genetic variation of antigen processing machinery components and association with cervical carcinoma," Genes Chromosomes and Cancer, vol. 46, no. 6, pp. 577-586, 2007.

[42] A. M. Mehta, V. M. Spaans, N. B. Mahendra et al., "Differences in genetic variation in antigen-processing machinery components and association with cervical carcinoma risk in two Indonesian populations," Immunogenetics, vol. 67, no. 5-6, pp. 267-275, 2015.

[43] M. H. Einstein, S. Leanza, L. G. Chiu et al., "Genetic variants in TAP are associated with high-grade cervical neoplasia," Clinical Cancer Research, vol. 15, no. 3, pp. 1019-1023, 2009.

[44] C. Natter, S. Polterauer, J. Rahhal-Schupp et al., "Association of TAP gene polymorphisms and risk of cervical intraepithelial neoplasia," Disease Markers, vol. 35, no. 2, pp. 79-84, 2013.

[45] A. M. Mehta, E. S. Jordanova, W. E. Corver et al., "Single nucleotide polymorphisms in antigen processing machinery component ERAP1 significantly associate with clinical outcome in cervical carcinoma," Genes, Chromosomes \& Cancer, vol. 48, no. 5, pp. 410-418, 2009.

[46] W. Yu, M. Gwinn, M. Clyne, A. Yesupriya, and M. J. Khoury, "A navigator for human genome epidemiology," Nature Genetics, vol. 40, no. 2, pp. 124-125, 2008.

[47] M. Zhao, L. Qiu, N. Tao et al., "HLA DRB allele polymorphisms and risk of cervical cancer associated with human papillomavirus infection: a population study in China," European Journal of Gynaecological Oncology, vol. 34, no. 1, pp. 54-59, 2013.

[48] I. Kohaar, S. Hussain, N. Thakur et al., "Association between human leukocyte antigen class II alleles and human papillomavirus-mediated cervical cancer in Indian women," Human Immunology, vol. 70, no. 4, pp. 222-229, 2009.

[49] X. Zhang, Z. Lv, H. Yu, F. Wang, and J. Zhu, “The HLA-DQB1 gene polymorphisms associated with cervical cancer risk: a meta-analysis," Biomedicine and Pharmacotherapy, vol. 73, pp. 58-64, 2015.

[50] L.-Z. Wei, H.-L. Wang, X. Liu et al., "Meta-analysis on the relationship between HLA-DRBl gene polymorphism and cervical cancer in Chinese population," PLoS ONE, vol. 9, no. 2, Article ID e88439, 2014.

[51] D. Chen and U. Gyllensten, "Systematic investigation of contribution of genetic variation in the HLA-DP region to cervical cancer susceptibility," Carcinogenesis, vol. 35, no. 8, pp. 17651769, 2014.

[52] M. Zoodsma, I. M. Nolte, G. J. Te Meerman, E. G. E. De Vries, and A. G. J. Van der Zee, "HLA genes and other candidate genes involved in susceptibility for (pre)neoplastic cervical disease," International Journal of Oncology, vol. 26, no. 3, pp. 769-784, 2005.

[53] D. Chen, I. Juko-Pecirep, J. Hammer et al., "Genome-wide association study of susceptibility loci for cervical cancer," 
Journal of the National Cancer Institute, vol. 105, no. 9, pp. 624633, 2013.

[54] M. J. Song, C. W. Lee, J. H. Kim et al., "Association of KIR genes and HLA-C alleles with HPV-related uterine cervical disease in Korean women," Tissue Antigens, vol. 81, no. 3, pp. 164-170, 2013.

[55] R. Rizzo, V. Gentili, A. Rotola, D. Bortolotti, E. Cassai, and D. Di Luca, "Implication of HLA-C and KIR alleles in human papillomavirus infection and associated cervical lesions," Viral immunology, vol. 27, no. 9, pp. 468-470, 2014.

[56] O. S. Miettinen, "Proportion of disease caused or prevented by a given exposure, trait or intervention," American Journal of Epidemiology, vol. 99, no. 5, pp. 325-332, 1974.

[57] G. Dranoff, "Cytokines in cancer pathogenesis and cancer therapy," Nature Reviews Cancer, vol. 4, no. 1, pp. 11-22, 2004.

[58] M. Clerici, M. Merola, E. Ferrario et al., "Cytokine production patterns in cervical intraepithelial neoplasia: association with human papillomavirus infection," Journal of the National Cancer Institute, vol. 89, no. 3, pp. 245-250, 1997.

[59] B. S. Chagas, A. P. A. D. Gurgel, H. L. A. da Cruz et al., "An interleukin-10 gene polymorphism associated with the development of cervical lesions in women infected with Human Papillomavirus and using oral contraceptives," Infection, Genetics and Evolution, vol. 19, pp. 32-37, 2013.

[60] S. K. Hussain, M. M. Madeleine, L. G. Johnson et al., "Nucleotide variation in IL-10 and IL-12 and their receptors and cervical and vulvar cancer risk: a hybrid case-parent triad and case-control study," International Journal of Cancer, vol. 133, no. 1, pp. 201-213, 2013.

[61] T.-Y. Shi, M.-L. Zhu, J. He et al., "Polymorphisms of the Interleukin 6 gene contribute to cervical cancer susceptibility in Eastern Chinese women," Human Genetics, vol. 132, no. 3, pp. 301-312, 2013.

[62] S.-S. Han, E.-Y. Cho, T. S. Lee et al., "Interleukin-12 p40 gene (IL12B) polymorphisms and the risk of cervical caner in Korean women," European Journal of Obstetrics Gynecology and Reproductive Biology, vol. 140, no. 1, pp. 71-75, 2008.

[63] G. Barbisan, L. O. Pérez, A. Contreras, and C. D. Golijow, "TNF- $\alpha$ and IL-10 promoter polymorphisms, HPV infection, and cervical cancer risk," Tumor Biology, vol. 33, no. 5, pp. 15491556, 2012.

[64] S. Wang, H. Sun, Y. Jia et al., "Association of 42 SNPs with genetic risk for cervical cancer: an extensive meta-analysis," BMC Medical Genetics, vol. 16, no. 1, article no. 25, 2015.

[65] H. Wajant, K. Pfizenmaier, and P. Scheurich, "Tumor necrosis factor signaling," Cell Death and Differentiation, vol. 10, no. 1, pp. 45-65, 2003.

[66] A. Kirkpatrick, J. Bidwell, A. J. C. Van Den Brule, C. J. L. M. Meijer, J. Pawade, and S. Glew, "TNF $\alpha$ polymorphism frequencies in HPV-associated cervical dysplasia," Gynecologic Oncology, vol. 92, no. 2, pp. 675-679, 2004.

[67] Y. Jin, "Association of single nucleotide polymorphisms in tumor necrosis factor-alpha with cervical cancer susceptibility," Cell Biochemistry and Biophysics, vol. 71, no. 1, pp. 77-84, 2014.

[68] M. Ghaderi, L. Nikitina, C. S. Peacock et al., "Tumor necrosis factor a-11 and DR15-DQ6 $\left(\mathrm{B}^{\star} 0602\right)$ haplotype increase the risk for cervical intraepithelial neoplasia in human papillomavirus 16 seropositive women in Northern Sweden," Cancer Epidemiology Biomarkers and Prevention, vol. 9, no. 10, pp. 1067-1070, 2000 .
[69] M. Ghaderi, L. N. Zake, K.-L. Wallin et al., "Tumor necrosis factor A and MHC class I chain related gene A (MIC-A) polymorphisms in Swedish patients with cervical cancer," Human Immunology, vol. 62, no. 10, pp. 1153-1158, 2001.

[70] W. H. Jang, Y.-I. Yang, S. S. Yea et al., “The -238 tumor necrosis factor- $\alpha$ promoter polymorphism is associated with decreased susceptibility to cancers," Cancer Letters, vol. 166, no. 1, pp. 4146, 2001.

[71] K. Schroder, P. J. Hertzog, T. Ravasi, and D. A. Hume, "Interferon- $\gamma$ : an overview of signals, mechanisms and functions," Journal of Leukocyte Biology, vol. 75, no. 2, pp. 163-189, 2004.

[72] F. P. Schena, G. Cerullo, D. D. Torres et al., "Role of interferon$\gamma$ gene polymorphisms in susceptibility to IgA nephropathy: a family-based association study," European Journal of Human Genetics, vol. 14, no. 4, pp. 488-496, 2006.

[73] A. P. Fernandes, M. A. Gonçalves, R. T. Simões, C. T. MendesJunior, G. Duarte, and E. A. Donadi, "A pilot case-control association study of cytokine polymorphisms in Brazilian women presenting with HPV-related cervical lesions," European Journal of Obstetrics \& Gynecology and Reproductive Biology, vol. 140, no. 2, pp. 241-244, 2008.

[74] V. B. Guzman, A. Yambartsev, A. Goncalves-Primo et al., "New approach reveals CD28 and IFNG gene interaction in the susceptibility to cervical cancer," Human Molecular Genetics, vol. 17, no. 12, pp. 1838-1844, 2008.

[75] E. L. Ivansson, I. Juko-Pecirep, and U. B. Gyllensten, "Interaction of immunological genes on chromosome 2q33 and IFNG in susceptibility to cervical cancer," Gynecologic Oncology, vol. 116, no. 3, pp. 544-548, 2010.

[76] W. P. Arend, "The balance between IL-1 and IL-1Ra in disease," Cytokine and Growth Factor Reviews, vol. 13, no. 4-5, pp. 323340, 2002.

[77] D. M. Kordi Tamandani, R. C. Sobti, M. Shekari, S. Kaur, and A. Huria, "Impact of polymorphism in IL-1RA gene on the risk of cervical cancer," Archives of Gynecology and Obstetrics, vol. 277, no. 6, pp. 527-533, 2008.

[78] C. Grimm, R. Watrowski, K. Baumühlner et al., "Genetic variations of interleukin-1 and -6 genes and risk of cervical intraepithelial neoplasia," Gynecologic Oncology, vol. 121, no. 3, pp. 537-541, 2011.

[79] Hamidullah, B. Changkija, and R. Konwar, "Role of interleukin10 in breast cancer," Breast Cancer Research and Treatment, vol. 133, no. 1, pp. 11-21, 2012.

[80] S. Mocellin, F. M. Marincola, and H. A. Young, "Interleukin10 and the immune response against cancer: a counterpoint," Journal of Leukocyte Biology, vol. 78, no. 5, pp. 1043-1051, 2005.

[81] Y. Wang, X. H. Liu, Y. H. Li, and O. Li, "The paradox of IL-10mediated modulation in cervical cancer," Biomedical Reports, vol. 1, no. 3, pp. 347-351, 2013.

[82] D. M. Turner, D. M. Williams, D. Sankaran, M. Lazarus, P. J. Sinnott, and I. V. Hutchinson, "An investigation of polymorphism in the interleukin-10 gene promoter," European Journal of Immunogenetics, vol. 24, no. 1, pp. 1-8, 1997.

[83] F. Farzaneh, S. A. Roberts, D. Mandal et al., “The IL-10-1082G polymorphism is associated with clearance of HPV infection," BJOG, vol. 113, no. 8, pp. 961-964, 2006.

[84] J. W. Roh, M. H. Kim, S. S. Seo et al., "Interleukin-10 promoter polymorphisms and cervical cancer risk in Korean women," Cancer Letters, vol. 184, no. 1, pp. 57-63, 2002. 
[85] K. Szöke, A. Szalmás, G. Szládek et al., "IL-10 promoter nt 1082A/G polymorphism and human papillomavirus infection in cytologic abnormalities of the uterine cervix," Journal of Interferon and Cytokine Research, vol. 24, no. 4, pp. 245-251, 2004.

[86] S. S. Wang, P. Gonzalez, K. Yu et al., "Common genetic variants and risk for HPV persistence and progression to cervical cancer," PLoS ONE, vol. 5, no. 1, Article ID e8667, 2010.

[87] J. Folkman, “The role of angiogenesis in tumor growth," Seminars in Cancer Biology, vol. 3, no. 2, pp. 65-71, 1992.

[88] C. C. Bleul, R. C. Fuhlbrigge, J. M. Casasnovas, A. Aiuti, and T. A. Springer, "A highly efficacious lymphocyte chemoattractant, stromal cell-derived factor 1 (SDF-1)," Journal of Experimental Medicine, vol. 184, no. 3, pp. 1101-1109, 1996.

[89] M. Kucia, K. Jankowski, R. Reca et al., "CXCR4-SDF-1 signalling, locomotion, chemotaxis and adhesion," Journal of Molecular Histology, vol. 35, no. 3, pp. 233-245, 2004.

[90] J. Libura, J. Drukala, M. Majka et al., "CXCR4-SDF-1 signaling is active in rhabdomyosarcoma cells and regulates locomotion, chemotaxis, and adhesion," Blood, vol. 100, no. 7, pp. 2597-2606, 2002.

[91] L. Yu, J. Cecil, S.-B. Peng et al., "Identification and expression of novel isoforms of human stromal cell-derived factor 1," Gene, vol. 374, no. 1-2, pp. 174-179, 2006.

[92] M. Gleichmann, C. Gillen, M. Czardybon et al., "Cloning and characterization of SDF- $1 \gamma$, a novel SDF-1 chemokine transcript with developmentally regulated expression in the nervous system," European Journal of Neuroscience, vol. 12, no. 6, pp. 1857-1866, 2000.

[93] R. Kimura, T. Nishioka, A. Soemantri, and T. Ishida, "Allelespecific transcript quantification detects haplotypic variation in the levels of the SDF-1 transcripts," Human Molecular Genetics, vol. 14, no. 12, pp. 1579-1585, 2005.

[94] G. A. Diaz, "CXCR4 mutations in WHIM syndrome: a misguided immune system?" Immunological Reviews, vol. 203, pp. 235-243, 2005.

[95] P. A. Hernandez, R. J. Gorlin, J. N. Lukens et al., "Mutations in the chemokine receptor gene CXCR4 are associated with WHIM syndrome, a combined immunodeficiency disease," Nature Genetics, vol. 34, no. 1, pp. 70-74, 2003.

[96] A. Strasser, P. J. Jost, and S. Nagata, "The many roles of FAS receptor signaling in the immune system," Immunity, vol. 30, no. 2, pp. 180-192, 2009.

[97] S. Kanemitsu, K. Ihara, A. Saifddin et al., "A functional polymorphism in Fas (CD95/APO-1) gene promoter associated with systemic lupus erythematosus," Journal of Rheumatology, vol. 29, no. 6, pp. 1183-1188, 2002.

[98] K. Sibley, S. Rollinson, J. M. Allan et al., "Functional FAS promoter polymorphisms are associated with increased risk of acute myeloid leukemia," Cancer Research, vol. 63, no. 15, pp. 4327-4330, 2003.

[99] J. Wu, C. Metz, X. Xu et al., "A novel polymorphic CAAT/ enhancer-binding protein $\beta$ element in the FasL gene promoter alters Fas ligand expression: a candidate background gene in African American systemic lupus erythematosus patients," The Journal of Immunology, vol. 170, no. 1, pp. 132-138, 2003.

[100] T. H. Mogensen, "Pathogen recognition and inflammatory signaling in innate immune defenses," Clinical Microbiology Reviews, vol. 22, no. 2, pp. 240-273, 2009.
[101] H.-S. Shin, F. Xu, A. Bagchi et al., "Bacterial lipoprotein TLR2 agonists broadly modulate endothelial function and coagulation pathways in vitro and in vivo," The Journal of Immunology, vol. 186, no. 2, pp. 1119-1130, 2011.

[102] H.-D. Nischalke, M. Coenen, C. Berger et al., "The toll-like receptor 2 (TLR2) -196 to $-174 \mathrm{del} /$ ins polymorphism affects viral loads and susceptibility to hepatocellular carcinoma in chronic hepatitis C,' International Journal of Cancer, vol. 130, no. 6, pp. 1470-1475, 2012.

[103] R. J. Soberman, C. R. MacKay, C. A. Vaine et al., "CD200R1 supports $\mathrm{HSV}-1$ viral replication and licenses pro-inflammatory signaling functions of TLR2," PLoS ONE, vol. 7, no. 10, Article ID e47740, 2012.

[104] H. Long, B. P. O’Connor, R. L. Zemans, X. Zhou, I. V. Yang, and D. A. Schwartz, "The Toll-like receptor 4 polymorphism Asp299Gly but not Thr399Ile influences TLR4 signaling and function," PLoS ONE, vol. 9, no. 4, Article ID e93550, 2014.

[105] U. A. Hasan, E. Bates, F. Takeshita et al., "TLR9 expression and function is abolished by the cervical cancer-associated human papillomavirus type 16," Journal of Immunology, vol. 178, no. 5, pp. 3186-3197, 2007.

[106] P. Leone, E.-C. Shin, F. Perosa, A. Vacca, F. Dammacco, and V. Racanelli, "MHC class I antigen processing and presenting machinery: organization, function, and defects in tumor cells," Journal of the National Cancer Institute, vol. 105, no. 16, pp. 11721187, 2013.

[107] D. M. Kordi Tamandani, R. C. Sobti, M. Shekari, S. A. Husseini, and V. Suri, "No association of TAP1 and TAP2 genes polymorphism with risk of cervical cancer in north Indian population," Journal of Assisted Reproduction and Genetics, vol. 26, no. 4, pp. 173-178, 2009.

[108] E. P. Hong and J. W. Park, "Sample size and statistical power calculation in genetic association studies," Genomics \& Informatics, vol. 10, no. 2, pp. 117-122, 2012.

[109] L. Zhang, R. Liu, Z. Wang, D. A. Culver, and R. Wu, "Modeling haplotype-haplotype interactions in case-control genetic association studies," Frontiers in Genetics, vol. 3, article 2, Article ID Article 2, 2012.

[110] D. Chen and U. Gyllensten, "Lessons and implications from association studies and post-GWAS analyses of cervical cancer," Trends in Genetics, vol. 31, no. 1, pp. 41-54, 2015.

[111] D. Charron, "HLA, immunogenetics, pharmacogenetics and personalized medicine," Vox Sanguinis, vol. 100, no. 1, pp. 163166, 2011.

[112] Q. Yan, "Immunoinformatics and systems biology methods for personalized medicine," Methods in Molecular Biology, vol. 662, pp. 203-220, 2010.

[113] R. J. Litjens, A. H. Hopman, K. K. van de Vijver, F. C. S. Ramaekers, R. F. P. M. Kruitwagen, and A.-J. Kruse, "Molecular biomarkers in cervical cancer diagnosis: a critical appraisal," Expert Opinion on Medical Diagnostics, vol. 7, no. 4, pp. 365377, 2013.

[114] T. J. Kim, H.-T. Jin, S.-Y. Hur et al., "Clearance of persistent HPV infection and cervical lesion by therapeutic DNA vaccine in CIN3 patients," Nature Communications, vol. 5, article 5317, 2014. 


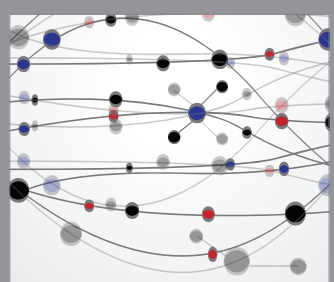

The Scientific World Journal
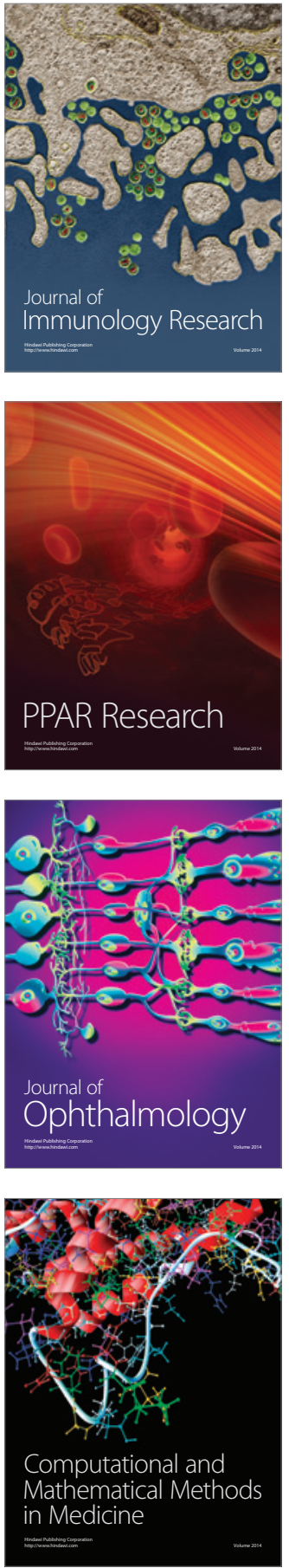

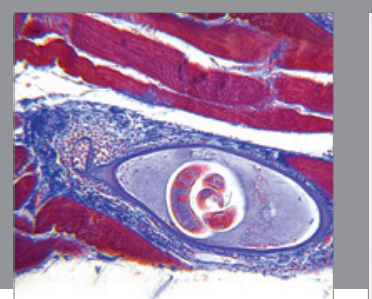

Gastroenterology Research and Practice
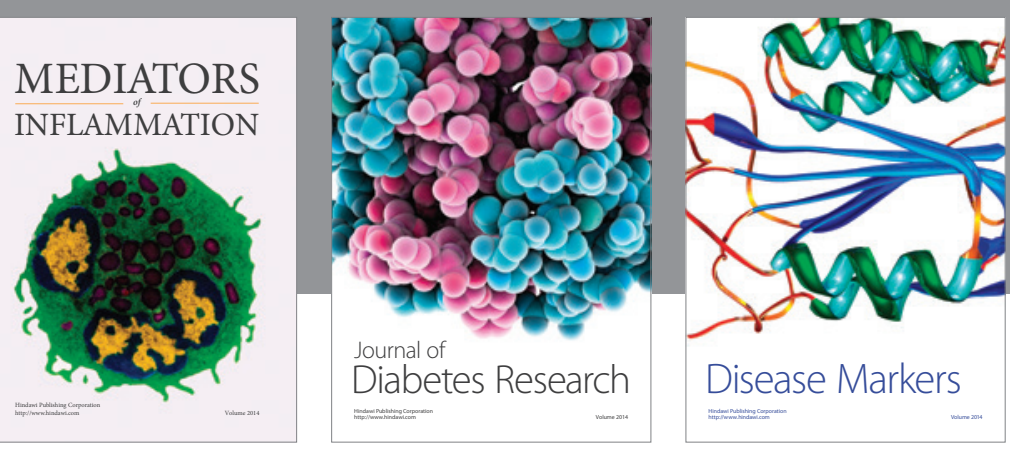

Disease Markers

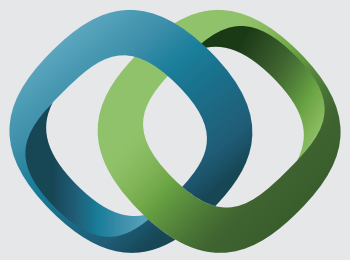

\section{Hindawi}

Submit your manuscripts at

https://www.hindawi.com
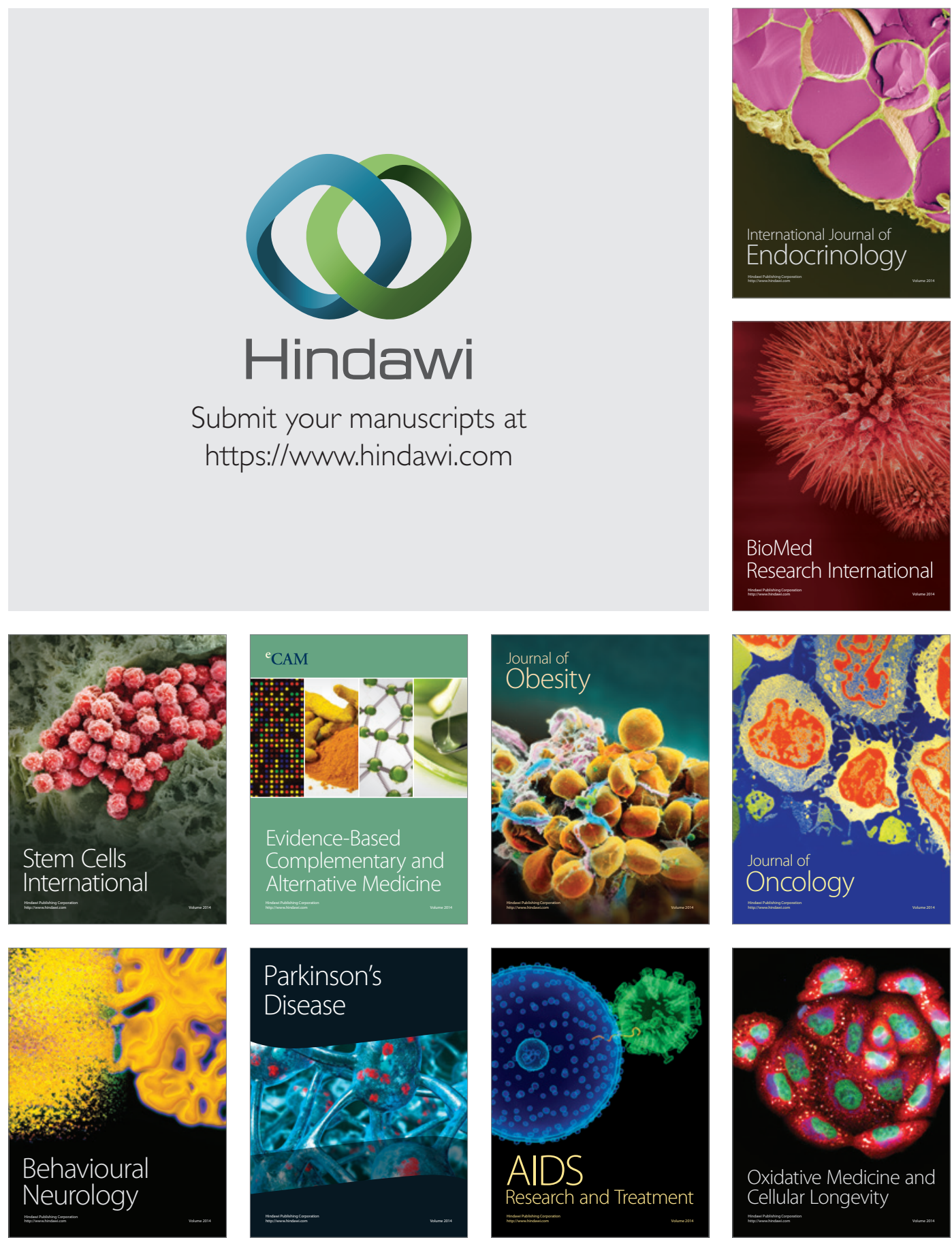